\title{
The New Students: What They Read
}

\begin{abstract}
Who are the new students of the 1970s, and how can those of us who work with them come to understand them better? It has been said, "A man is what he reads." An analysis of student tastes in pleasure reading, as reflected in the campus bookstore best-seller lists compiled by the Chronicle of Higher Education, reveals that students today are seeking new perspectives in their quest for personal identity.
\end{abstract}

I

IN THE LATE 1960s, when students were posing problems to their elders, there was a great outpouring of commentary on youth. There were sociological and political analyses of protests, clinical studies of activist and alienated students, and anthropological treatises on the generation gap. But when the students quieted down, the flood of descriptive literature ceased. A "new student" emerged, but few of the elders cared to comment.

Who are the new students, and how can those of us who work with them come to understand them better? It has been said, "A man is what he reads." Today we might better say people are what they read, watch, and listen to; but it is probably still true that what a person reads reflects, in part, what that person is. Reading tastes give us a glimpse of a person's consciousnessconsciousness in the sense that Charles Reich defined it in the Greening of America: "the total configuration in any given individual, which makes up his whole perception of reality, his whole world view."

James R. Davis is associate professor of higher education, University of Denver, Denver, Colorado.
A periodical, the Chronicle of Higher Education, read by many college faculty and administrators, runs a student bestseller list, a survey based on high-volume sales at various college bookstores. From time to time surveys of individual campuses are brought together into a composite best-seller list reflecting the tastes of some fifty to seventy-five campuses. Through an analysis of these lists for the first three years of the 1970s and, in turn, an examination of the most popular books named there, it is possible to get a fairly accurate picture of students' pleasure reading and, by inference, their consciousness. Students' choices fall into various categories.

\section{The Nature of Society}

First of all, students read many of the same best sellers read by the general public. Consistently high on the student best-seller lists are books such as Toffler's Future Shock, Uris' QB VII, Blatty's The Exorcist, and Reich's The Greening of America. Surprisingly to some, perhaps, students are willing to tackle long and sometimes difficult books such as Solzhenitsyn's August 1914, Halberstam's The Best and the Brightest, and Skinner's Beyond Freedom and Dignity. Many of the most popular books are 
also movies, such as Puzo's The Godfather, Raucher's The Summer of '42, Burgess' A Clockwork Orange, and Forsyth's The Day of the Jackal. Many of these works attempt to provide perspective on our society or the world in which we live. They raise questions about where we are going and how we got where we are. They explore the powers of human beings to shape and control their world. These are questions that confront us all, but they are especially burning questions to college students. Questions about the nature of society and one's relationship to it, though posed with less harshness than in the 1960 s, are still very much in students' minds.

\section{SELF-UNDERSTANDING}

Books on psychology and self-understanding form a second category of best sellers. It is not surprising that Harris' I'm OK, You're OK: A Practical Guide to Transactional Analysis is consistently on the composite best-seller list. Most students are struggling to move from child to adult roles. In the process, their parents often pose problems to them; and students realize that they, in turn, pose problems to their parents. Students welcome some clarification about what it might be like for them (and their parents) to stop playing parent and child roles and to begin playing adult roles. In addition, they find the elements of transactional analysis applicable to a dependent (or domineering) roommate. Other popular titles include Janov's Primal Scream (an impulse most of us have had in college), Kubler-Ross' Questions and Answers on Death and Dying, Fast's Body Language, and Laing's Knots. Several of Perls' books are popular, including Gestalt Therapy Verbatim and In and Out the Garbage Pail. If the sensitivity movement has passed its zenith, the search for more open and genuine human relationships has not.

\section{ReLigion}

Oddly enough, the search for self-understanding has included almost no books on religion, with one notable exception, Gibran's The Prophet. Students do not read theology as students read Niebuhr, Tillich, Buber, and Kirkegaard some years ago. Students' search for identity today takes place in a more personal context, and involvements with religion, when they do occur, are more likely to include participation in mystical, nonrational sects and movements. Intellectual, discursive understanding of conventional religious traditions is apparently not sought.

On the other hand, The Prophet has sold more copies in campus bookstores than any other volume over the past five years. The work of a Lebanese mystic published in 1923, The Prophet describes in simple, poetic English the departure of the prophet Almustafa from the City of Orphalese to the island of his birth. Before he leaves, the prophet speaks words of wisdom to the citizens of the city. He says, for example, that these should be among one's desires:

"To melt and be like a running brook that sings its melody to the night.

"To know the pain of too much tenderness.

"To be wounded by your own understanding of love;

"And to bleed willingly and joyfully."

The teachings appeal to the emotions, they often reject rational understanding, and they express the mystical unity of man and nature. The words of wisdom come in short, memorable aphorisms and the movement is cinematic, rather than from one argument to the next. The teachings are intensely personal and immediately applicable.

\section{ANTISCIENCE}

Students' rejection of rational discourse about religion is probably part of a larger skepticism about scientific 
thought generally. This rejection of scientific rationalism, expressed as a rebellion against technocracy, was identified and examined in a book popular among students, Roszak's The Making of a Counter Culture. While the counter culture never produced the impact of "an invasion of Centaurs" (just as America never "greened"), there is no doubt that a pervasive skepticism about science persists in the minds of many students today. Students don't read books about science; they read some science fiction, but the popular books touching scientific themes are for the most part antiscientific in spirit. Watson's Double Helix is a personal account of the discovery of DNA, but its main thrust is that this scientific breakthrough involved a great amount of intuition, intelligent guessing, and "luck." The book doubtless owes its popularity to students' fascination with this side of the process. The most recent books to shoot to the top of the student best-seller lists are Von Däniken's Gods from Outer Space and Chariots of the Gods? Although Von Däniken proceeds in a logical, rational manner to try to establish that (a) life on other planets is likely, (b) interplanetary space travel from creatures on other planets is possible, (c) our planet was invaded by such travelers, and (d) ancient ruins which cannot be explained in any other way establish the evidence for such visits, it is clear that what he is trying to do is to shake to the very foundations the assumptions upon which our present "scientific" worldview is founded. It is science in the bullring against science, and students apparently are fascinated spectators.

\section{Fantasy}

It is only a small step from such fantastic ideas, presented in all seriousness, to fantasy. There is enough of the child left in students to enjoy fairy tales, but they have to be adult fairy tales. And students have their favorites. Some stu- dents have worked their way through all three volumes of Tolkien's Lord of the Rings, but their favorite has been The Hobbit. It is not a new book; it was published in 1937 by J. R. R. Tolkien, an Oxford don, a medievalist and philologist. The "hero" of the story, Bilbo Baggins, is a hobbit, a not-quite-human, short, fat creature with furry feet and natural leathery soles. Bilbo sets forth on a quest through all manner of strange terrain to return the One Ring of Power to the Shire. It is not so surprising that students like the hobbit; they identify with him. He's away from home on a quest; he encounters strange, unfamiliar surroundings; and he has to do a lot of what students call "coping." $\mathrm{He}$ is a minihero who is constantly thrown into situations not of his own making, but somehow he bumbles through. No matter how bad things get, he has hope. One might say his experiences are something like going to college.

\section{Social Issues}

In spite of their interest in fantasy, students are also interested in the real world. If their reading is any indication, they still have a deep concern for contemporary social issues, particularly the relationship of the races and the protection of the environment. Popular books about blacks tend to be autobiographical statements by blacks, such as Cleaver's Soul on Ice, Gregory's No More Lies, Davis' If They Come in the Morning, and, of course, The Autobiography of Malcom X. Students today, instead of involving themselves in protest movements for racial justice, seem to be saying to blacks, "Tell us what you're like and how you see it." Interest in persons of other races has been broadened to include the American Indian. Two books in particular have been especially popular, Brown's Bury My Heart at Wounded Knee and Deloria's Custer Died for Your Sins.

Students continue to express interest 
in environmental problems, and they buy such books as Commoner's The Closing Circle, Ehrlich's The Population Bomb, and Morris' The Human Zoo. Commoner's lucid exposition of the key problems producing the ecological crisis is an example of how a professor can present complex scientific principles in a style that is popular and palatable to students.

\section{SEX}

And then there is sex. It has been said that Americans are generally hung up on it, and students are probably no less so, if we are to judge from their reading. The books fall into several subcategories. There are those on mechanics. Since many students, as a mere function of their age, are inexperienced, they want to know how. (Oddly enough, our culture has apparently produced a number of fully grown, even aging, adults who also want to know how.) And so students read Reuben's Everything You Always Wanted to Know about Sex...., The Sensuous Man by "M," The Sensuous Woman by "J," and (at least at Yale) the Student Guide to Sex on Campus by the Student Committee on Sexuality. Interest in sexuality also includes some thoughtful reflection on sex roles, sexual stereotyping, and discrimination against women. Such interests are doubtless sparked by the women's movement, but for whatever reasons, students in significant numbers are reading Greer's The Female Eunich and Kate Millett's Sexual Politics. (So far little has been written on the role stereotyping which men encounter.) Students also seem to be interested in discovering the meaning of sex in the context of love and marriage, as evidenced by the popularity of Bach and Wyden's Intimate Enemy: How to Fight Fair in Love and Marriage and the O'Neills' Open Marriage. The overwhelming popularity of Segal's Love Story, quite apart from its appeal to emotion, must be seen at least in part as a result of its positive portrayal of a youthful sexual relationship within the context of love-in short, a real love story.

\section{LEISURE}

Most of the books cited above provide some insight into what students think about. Another set of titles suggests what they do, how they occupy their leisure. One thing they do is more of their own cooking. The trend toward off-campus living arrangements has been accompanied by an intense interest in diet and health. Among the best sellers in this category are Davis' Let's Eat Right to Keep Fit, Atkins' Dr. Atkins' Diet Revolution, and Pauling's Vitamin $C$ and the Common Cold. Students are buying cookbooks such as Hunter's The Natural Foods Cookbook, Sunset's Sunset Cookbook of Breads, Brown's Tassajara Bread Book, and, in the South, The Plantation Cookbook published by the Junior League of New Orleans. Students are still eating some rather strange meals, but at least they are getting the satisfaction of preparing the menu themselves.

The interest in natural foods is part of a wider back-to-nature movement. Many students are spending time out of doors trying to appreciate and enjoy whatever natural environment may be accessible, and they buy books to enhance their understanding. These books are regional best sellers, and may be popular on only a few campuses. At Delaware State students are buying Leopold's Sand County Almanac, at Tulane they purchase Brown's Wild Flowers of Louisiana, at North Carolina State they read Peterson's Field Guide to Birds, at San Fernando Valley State College they buy Iacopi's Earthquake Country, and at Dartmouth it's Foley's What the Old-Timer Said to the Feller from Down-Country and Even to His Neighbor When He Had It Coming. 
Students are also trying their hands at crafts that use natural materials, such as leather work and pottery. To guide their efforts they buy books such as Pesch's Macramé and even the Better Homes and Gardens book on Flower Arranging. The classic compendium of folk crafts and "natural" wisdom is Brand's The Last Whole Earth Catalog.

Students still attend football games, of course, but their interests in sports tend toward individual skills that play down competition. At least that seems to be what is reflected in their purchase of Caldwell's New Cross-Country Ski Book, Laing's American Sail: A Pictorial History, and Fletcher's The Complete Walker.

\section{Drugs}

Ironically, or at least with some contradiction, the interest in natural diet, health, and outdoor living is accompanied by a strong interest in books that record drug experiences. The readers, of course, may be different readers, but somewhere on the composite best-seller lists appears at least one of the books by Castaneda, The Teachings of Don Juan, A Separate Reality, or Journey to Ixtlan. In The Teachings of Don Juan, the author, supposedly an anthropology graduate student at UCLA, records in diary form his five years of initiation into drug experiences with Don Juan, a Yaqui Indian from Sonora, Mexico. The Indian is a brujo, a medicine mansorcerer, and he teaches the author the uses of various kinds of plants (in particular peyote, which becomes anthropomorphized as "Mescalito") to induce states of "non-ordinary reality." The book consists mainly of detailed descriptions of drug preparation rituals and hallucinogenic states. For those who participate, and there are doubtless many, this becomes a handy-reference to the joys and terrors of an expanded consciousness.

\section{NOveLS}

Students read little poetry, with the exception of collections by Rod McKuen, Leonard Cohen, and Sylvia Plath; but they do read novels. The novels don't always make the best-seller lists because students read an author and may select from any one of several books the author has written. Many students have read at least one book by Richard Brautigan, Kurt Vonnegut, and Hermann Hesse.

Brautigan is the prophet of the absurd, and students especially like Trout Fishing in America, A Confederate General from Big Sur, and The Abortion: An Historical Romance 1966? The titles convey well what Brautigan is about, and if you read them carefully you may not need to read the books. Brautigan is a master at creating vivid images of the absurd: an old woman living on a government pension of thirty-five cents a month, a girl so strikingly beautiful that men run into things while watching her, and a library where books are never accepted by mail but must be brought in person. To students who have come to feel that much that passes for culture, civilization, and wisdom is absurd, Brautigan's images have a ring of truth.

Vonnegut deals with many themes that appeal to students, and they especially like Cat's Cradle, SlaughterhouseFive (also a successful movie), and a collection of his shorter works, Welcome to the Monkey House. Vonnegut is a convincing critic of war, violence, and the military mind. His portrayal of time travel suggests the mysticism of certain Far Eastern religions and drug trips. He portrays the imminent destruction of the world at the hands of science and technology, for example through "ice-nine," that miraculous invention that turns all water (and everything with water in it) into a solid and 
eventually destroys all life on earth.

Students also read the novels of Hermann Hesse, a German novelist and winner of the Nobel prize in 1946. His most popular novel is Siddhartha, written in 1922, but students also are reading his later works, Steppenwolf and Journey to the East. Siddhartha is the story of a pilgrim in search of his own identity. Students today identify with Siddhartha's explorations of what they would call "alternative life-styles" (the way of asceticism, the way of worldly pleasure) in his search for personal fulfillment. Hesse's portrayal of intense existential searching, blended with the aphoristic wisdom of the Far East, is attractive and appealing to students.

\section{SumMary}

If students are, at least in part, what they read, what understanding of their consciousness emerges from this popular array of widely read books? The picture that develops is that of a young person seeking perspective on the society and world in which he lives; if not rebellious against, at least suspicious of the conventional world-view provided by his religious tradition, eighteenth-century rationalism, and modern science. He mistrusts the technology that keeps the world hovering on the eschatological brink and seeks a better life by restoring man's primal unity with nature. To discover his personal identity in a world that seems always to border on the absurd, he turns inward, seeking a better understanding of himself and his dayto-day relationships with parents, those of the opposite sex, and members of other races. In his inward journey he does not shrink from fantasy or the drug-induced states of nonordinary reality. $\mathrm{He}$ has no master plan for his existential quest; he just blunders through, Hobbit-like, learning to cope by gathering up aphoristic bits and pieces of meaning wherever he can find them.

The new student is summed up in Bach's Jonathan Livingston Seagull, a book that almost every student today has read. Jonathan "learns" by climbing high to get perspective on his world, by developing and testing the powers of his being, by talking back upon occasion to the Council Flock, and by discovering that he can do more than he expected. $\mathrm{He}$ becomes a one-in-a-million bird. What he had once hoped for the Flock he now gains for himself alone, transcending space and time, eventually learning the meaning of kindness and love. Above all he learns that freedom is the very nature of his being.

Students come in all shapes and sizes, of course, and with all manner of forms of consciousness. But if many of them are like the student described above, there is some question whether today's colleges and universities are equipped even to understand them, let alone meet their needs. It is doubtful whether many students share much of the agenda which their professors have for them; they have too many personal questions of higher priority. They may complete the agenda, even faithfully; they have been well trained for twelve years in that. But their "real education" grows out of an eclectic gathering of experiences found to be instrumental in their inward search for an authentic personal identity. The rest they deem irrelevant obligation. The essence of the traditional university, a rationalism which includes a vast array of sophisticated techniques for "objective," statistical quantification of data, is viewed with considerable skepticism and indifference. Those of us who teach, whatever our consciousness, might be more effective if we were to check more frequently on how our "professing" is being processed on the other side of the lectern by the new students. 